\title{
Western European housing systems and the impact of the international financial crisis
}

\author{
Harry van der Heijden · Kees Dol • Michael Oxley
}

Received: 15 May 2010/Accepted: 15 March 2011/Published online: 10 June 2011

(C) The Author(s) 2011. This article is published with open access at Springerlink.com

\begin{abstract}
The central proposition advanced in this paper is that differences in the structure of housing systems, and specifically the differences between dynamic and static housing systems, are crucial to an explanation of the varying impacts between countries of the international financial crisis. The proposition is illustrated with reference to Ireland, England, the Netherlands, Belgium and Germany. The impacts on housing markets and housing policies are considered and it is shown that these are more significant in dynamic than in static systems. It is argued that whilst the classification of housing systems as dynamic and static adds an important new explanation for the varying impacts of the crisis, this is most usefully viewed as a complementary, rather than an alternative, perspective to other sets of explanations.
\end{abstract}

Keywords Housing system · Financial crisis · Housing market · Housing policy

\section{Introduction}

This paper shows that a common external shock in the form of the international credit crisis had varying housing impacts in different European countries. There are two sorts of impacts considered. The first are essentially housing market impacts represented by changes in house prices, transactions and output and the second are policy impacts that are

This contribution is based on a paper presented at the Joint Conference of the European Network for Housing Research (ENHR) Working Group on Comparative Housing Policy and the Asia-Pacific Network of Housing Research (APNHR) Comparative Housing Research: Approaches and Policy Challenges in a New International Era, 24th March, Faculty of Architecture, Delft University of Technology, The Netherlands.

H. van der Heijden $(\bowtie) \cdot$ K. Dol $\cdot$ M. Oxley

OTB Research Institute for the Built Environment, Delft University of Technology,

Delft, The Netherlands

e-mail: h.m.h.vanderheijden@tudelft.nl

M. Oxley

Centre for Comparative Housing Research, De Montfort University, Leicester, UK 
represented by the responses of government to the crisis. The policy responses that were aimed at finance systems can be distinguished from the responses that were specific to housing markets. Of the two sets of policy responses, this paper is primarily concerned with the housing policy responses. It is clear that both the housing market and housing policy responses varied considerably between countries, and this paper seeks to explain why. The central proposition advanced is that differences in the structure of housing systems and specifically the differences between dynamic and static housing systems are crucial to an explanation of the varying impacts. The proposition is illustrated with reference to Ireland, England, ${ }^{1}$ the Netherlands, Belgium ${ }^{2}$ and Germany. The German and Belgian housing systems are seen to be examples of static systems whilst the English, Irish and Dutch systems are dynamic. It will be shown that without crisis-related interventions each of the two types of systems has 'built-in' stabilising factors but these factors are stronger in static than in dynamic systems.

In the next section the nature of the external shock is defined. The subsequent sections then provide information on the impacts of the shock in the different countries. This is followed by considerations of explanations for varying impacts from the points of view of macroeconomic theory and housing systems analysis. The distinction between dynamic and static systems is then set out and applied to the five countries. The conclusions show that the classification of housing systems as dynamic and static adds an important new explanation to the varying impacts of the international crisis. This is most usefully viewed as a complementary, rather than an alternative, perspective to the sets of explanations that arise from theories embedded in macroeconomics and the economics of housing markets.

\section{The crisis}

At the beginning of 2007 the Mortgage Bankers Association reported increasing default of American homeowners (MBA 2007). As many over-indebted US households have variable-rate mortgages, a series of (minor) interest rate increases in 2006 rapidly led to default for many homebuyers. Indeed, mortgage lending can be very risky in the USA as a number of states have anti-deficiency laws (whereby on foreclosure the homeowner is not responsible for any deficit between the sale price and the outstanding mortgage). In the case of house price declines, this can result in substantial losses for banks. The initial fall in banking asset values is typically ascribed to the fact that several institutions, initially in the US but ultimately world-wide, were holding mortgage backed securities that were high risk and low value given the state of the American housing market and the degree of subprime lending. The uncertainty about further losses on these assets resulted in lack of confidence between banks and subsequently a 'credit crunch'. The global financial crisis amounted to a world-wide fall in the value of banks' assets, a consequent international reduction in inter-bank lending and a wider reduction in the availability of credit coupled with a loss of confidence in financial markets. The collapse of some financial institutions, a reduction in world trade and falls in economic output followed.

Direct effects on mortgage markets are obvious in the USA and the UK where credit standards were tightened (Federal Reserve 2008; CML 2008) and resulted in a strong reduction in subprime mortgage loans. In continental Europe there is no proof for a large subprime segment, although in recent years atypical contracts and high loan to values have

\footnotetext{
1 Some of the available information is based on the UK.

2 Most of the information used is based on Flanders, one of the three Belgian regions.
} 
been offered on European mortgage markets (ECB 2009). Another direct impact of the credit crunch was the wipe-out of the equity release mortgage market (Brunnermeier 2009). Statistics show clear evidence of massive equity release by American and British households before the financial crisis (see Bank of England 2010; Freddie Mac 2010). This would also apply to some other European countries. However, not all European countries allow equity release products (ECB 2009). On European markets, the subprime segment is very small, but tightening credit standards on the prime market led to refusals of specific groups like first-time buyers. Trading-up on the housing market can stagnate as soon as house prices level off. This is attributed to the general "wait and see environment" (see for instance CML 2008), whereas the availability of credit on the large prime European mortgage markets should not be held responsible for all declines in the demand for housing.

\section{The impact of the crisis (a) macroeconomic and housing market responses}

In the second half of 2008, the US credit crisis began to trigger a global crisis in the financial system that also spread to the real economy. In order to assess the impact of the financial crisis on the housing market, it is necessary to understand the degree to which the real economy has been affected. It should also be noted that effects on the housing market and in particular on the housing construction market will continue to be felt for a long time. It is therefore currently only possible to assess the interim situation.

Table 1 includes a range of economic indicators for the various countries included in the study. All five countries experienced a downturn in 2009 and, on balance, in the period 2008-2010 (according to forecasts). This downturn was by far the most significant in Ireland and the least in Belgium. In terms of unemployment, Ireland was also clearly the worst hit. Unemployment has also seen a strong increase in the UK since 2007, while in the Netherlands and Germany unemployment actually fell on balance in the period 2007 to mid-2009. The Netherlands clearly had the lowest unemployment levels. The mortgage interest rates were lowest in Ireland and highest in the Netherlands and Belgium.

As far as the impact of the economic crisis on the owner-occupied housing markets in the five countries is concerned, the drop in prices and number of sales in both existing housing stocks and new-build have been the greatest in Ireland, followed by the UK. Unfortunately, a number of indicators of recent trends in the owner-occupied housing market are unavailable for Germany and Belgium. For new-build dwellings in the owneroccupied sector, this is because of the large proportion of private individuals commissioning their own homes in these countries which means that there are no sales or sales prices for much of the new construction in the owner-occupied sector. Of the three continental markets, it appears that the market for new-build dwellings in the Netherlands has been badly hit and the market for existing owner-occupied dwellings in Germany has seen the most significant fall in price. The latter is partly a consequence of the large number of excess properties available in the housing market in Germany. The Belgian owner-occupied housing market appears to have been the least affected by the economic crisis.

Germany gives a striking example of the (as long as it lasts) immunity of the owneroccupied housing market for the crisis. House prices were already under pressure due to demographic change, while other housing market indicators show strong stability. This stability is even more pronounced in Belgium where house prices and sales of dwellings remained stable. The Dutch owner-occupied housing market has reacted to the crisis considerably, especially in terms of the sales of newly built dwellings. The English and 
Table 1 Recent economic developments and recent developments on the owner-occupied housing market in five West European countries

\begin{tabular}{|c|c|c|c|c|c|}
\hline & $\begin{array}{l}\text { The } \\
\text { Netherlands } \\
(\%)\end{array}$ & Belgium & Germany & Ireland $(\%)$ & UK \\
\hline \multicolumn{6}{|l|}{ Economic indicators } \\
\hline GDP, change in 2009 & -4.5 & $-2.9 \%$ & $-5.0 \%$ & -7.5 & $-4.8 \%$ \\
\hline $\begin{array}{l}\text { GDP, change 2008-2010 } \\
\text { (forecast) }\end{array}$ & -2.2 & $-1.3 \%$ & $-2.5 \%$ & -11.9 & $-3.3 \%$ \\
\hline Unemployment mid-2009 & 3.3 & $7.5 \%$ & $7.5 \%$ & 12.0 & $7.6 \%$ \\
\hline $\begin{array}{l}\text { Unemployment change } \\
\text { early } 2007 \text { to mid- } 2009\end{array}$ & -0.5-point & $0 \%$-point & $-1.6 \%$-point & 7.7-point & $2.1 \%$-point \\
\hline $\begin{array}{l}\text { Mortgage interest rate } \\
(\text { mid-2009) }\end{array}$ & 5.44 & $5.52 \%$ & $4.40 \%$ & 3.23 & $4.39 \%$ \\
\hline \multicolumn{6}{|l|}{ Housing market indicators } \\
\hline $\begin{array}{l}\text { House prices existing } \\
\text { dwellings, change early } \\
2008 \text { to mid- } 2009\end{array}$ & -7.1 & $0.2 \%$ & $-11.6 \%$ & -13.7 & $-16.6 \%$ \\
\hline $\begin{array}{l}\text { Sales of existing dwellings, } \\
\text { change early } 2007 \text { to } \\
\text { mid-2009 }\end{array}$ & -33.1 & - Stable $^{\mathrm{a}}$ & $\begin{array}{l}\text { Stable (based on } \\
\text { volume of new } \\
\text { loans) }\end{array}$ & -64.9 & $-53.1 \%$ \\
\hline $\begin{array}{l}\text { House prices newly built } \\
\text { dwellings, change early } \\
2008 \text { to mid- } 2009\end{array}$ & -10.7 & No data & $-0.2 \%$ & -21.4 & $-15.3 \%$ \\
\hline $\begin{array}{l}\text { Sales of newly built } \\
\text { dwellings, }{ }^{\text {b change }} \\
\text { early } 2007 \text { to mid-2009 }\end{array}$ & -62.0 & $\begin{array}{l}\text { Virtually } \\
\text { unchanged }\end{array}$ & $\begin{array}{l}\text { Virtually } \\
\text { unchanged }\end{array}$ & -71.6 & No data \\
\hline
\end{tabular}

Source: National statistical bureaus (in Dol et al. 2010a)

a OTB estimate based on summary data

b Belgium and Germany based on planning permission granted; UK based on construction started

Irish owner-occupied housing markets have overall, in terms of house prices and sales of dwellings, suffered most.

\section{The impact of the crisis (b) policy responses: (1) finance system measures}

In all the countries included in the study, governments intervened significantly in the financial market in order to restore confidence in the banking system and prevent the collapse of financial institutions. Of course, these measures also have an indirect effect on the housing market, in the form of financing for housing construction and the provision of mortgage loans. The first and foremost actions that the governments in the five countries took were measures to avoid a collapse of the financial sector. There are three types of measures that were taken by governments. First of all there are the direct capital injections to strengthen the liquidity of a bank so it can do normal business. The capital injections are usually a loan but sometimes a credit line in return for a share in the bank. Secondly the state can give guarantees for bank loans in order to limit risk and increase inter-bank and overall bank lending. Thirdly, the state can buy up toxic assets at a discount on the nominal value of which the actual value is unclear. The state will then eventually try and resell these assets in a later phase. 
Table 2 Stabilisation measures for the financial sector in $€$ billion (as of 20 February 2009)

\begin{tabular}{|c|c|c|c|c|c|c|}
\hline & \multicolumn{3}{|c|}{ Total reservation } & \multicolumn{3}{|c|}{ Total used/received } \\
\hline & $\begin{array}{l}\text { Capital } \\
\text { injection }\end{array}$ & $\begin{array}{l}\text { Guarantees } \\
\text { on loans }\end{array}$ & $\begin{array}{l}\text { Takeover of } \\
\text { toxic assets }\end{array}$ & $\begin{array}{l}\text { Capital } \\
\text { injection }\end{array}$ & $\begin{array}{l}\text { Guarantees } \\
\text { on loans }\end{array}$ & $\begin{array}{l}\text { Takeover of } \\
\text { toxic assets }\end{array}$ \\
\hline Ireland $^{\mathrm{a}}$ & 10 & 485 & 90 & 9 & 11 & 0 \\
\hline Netherlands & 20 & 200 & 55 & 31 & 17 & 0 \\
\hline UK & 55 & 273 & 0 & 40 & 58 & 0 \\
\hline Germany & 80 & 400 & 0 & 44 & 155 & 0 \\
\hline Belgium & 0 & 99 & 0 & 18 & 91 & 0 \\
\hline
\end{tabular}

Source: Hartmann (2009)

a Ireland, takeover of toxic assets in NAMA of June 2009, no assets were acquired immediately

Table 2 gives a summary of the crisis measures taken as of February 2009. It may not fully record all banking stability measures taken. For example in June 2009 the Irish government introduced NAMA, a $€ 90$ billion fund to buy up bad assets, mostly from property development loans. The left-hand part of the table sums up the reservations of central governments to stabilise the banking sector. The right-hand side gives an overview of how much the financial sector actually drew upon these facilities. These facilities clearly show extensive measures in all the five countries. Comparatively, by size of the population, the measures are largest in Ireland, the UK and the Netherlands, while they remain large, but relatively smaller in Belgium and Germany. Note also that Dutch and Belgian banks already received more in capital injections than their governments had expected.

\section{The impact of the crisis (b) policy responses: (2) housing system measures}

In terms of measures focusing directly on the housing market, the most noticeable aspect is that the German government has so far taken no direct measures with regard to the housing market, although incentives are available to encourage energy-saving renovations in largescale apartment blocks. This is again due to the large numbers of excess homes in large parts of Germany since the start of this century. In Belgium, limited crisis measures have been taken focusing directly on the housing market. These include providing incentives for construction (by means of a temporary reduction in VAT) and particularly ensuring the provision of social rental dwellings. The income limits for housing costs insurance funded by local authorities have also been relaxed.

The United Kingdom and Ireland have seen by far the greatest intervention and it is these countries which have been worst hit by the impact of the economic crisis on the housing market. In Ireland, the measures relate primarily to support for first-time buyers, the removal from the market of unsold new dwellings (through leasing by social landlords) and also to a lesser extent to prevent the eviction of households in payment arrears. The Irish measures for first-time buyers are intended to sustain the system of trading-up and promote home ownership. This reflects the structure of the Irish housing market, which has a small rental sector. The measures to remove unsold new dwellings from the market are part of an attempt by the Irish government to lessen the impact of speculative house building. The support offered to households facing problems with payment appears to be limited to the signing of a code of conduct with the Irish Federation of Banks. 


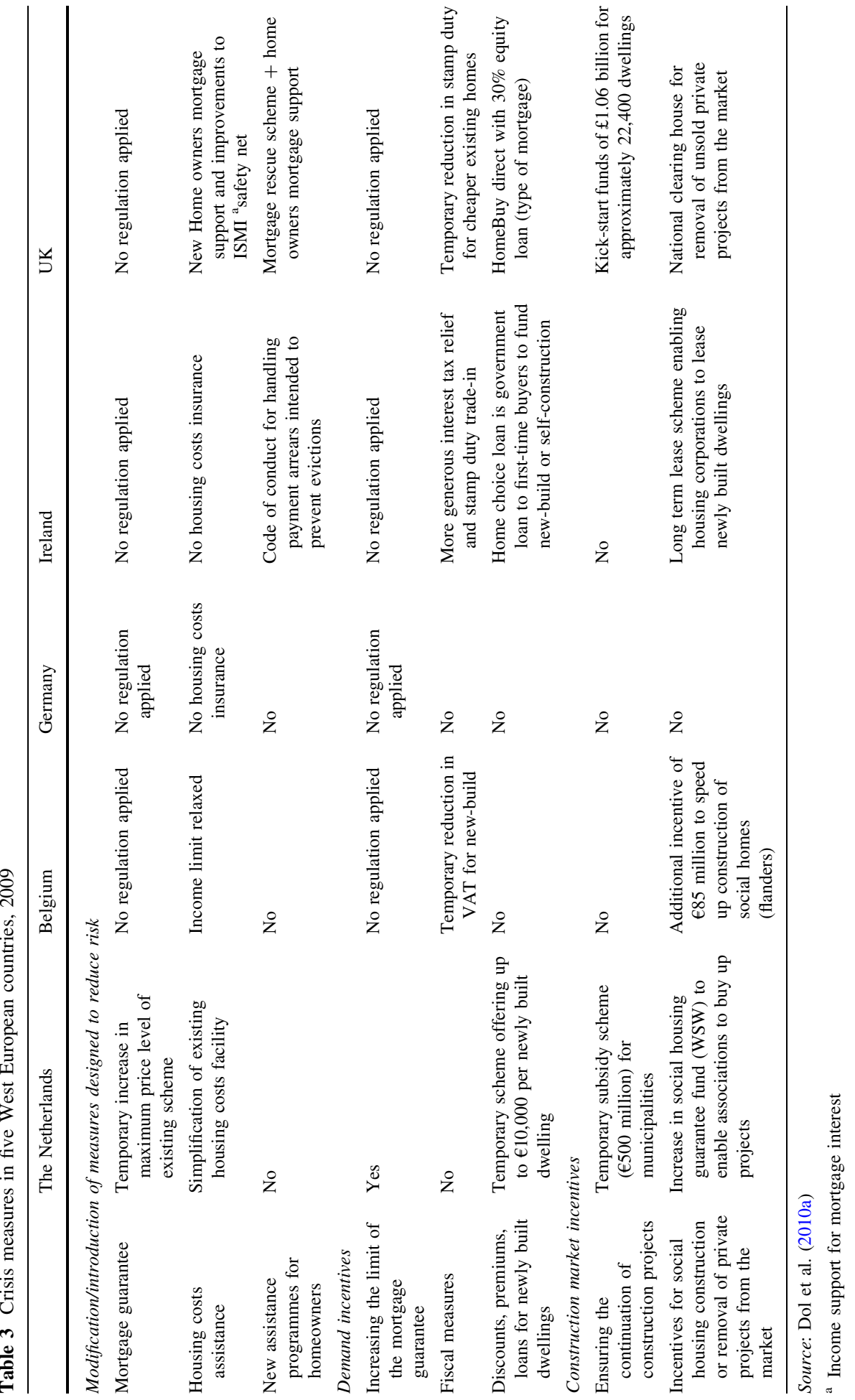


In the UK, a significant proportion of the measures taken by government were intended to support households unable to meet their payment commitments as a result of the crisis. The British government hoped that these measures would prevent evictions and inhibit further downward pressure on house prices. The British government took measures to remove unsold new dwellings from the market. It also provided incentives for the sale of existing affordable dwellings and the construction of new homes in the same category. These new homes include both private and rental properties and a new hybrid form of purchase/rental known as shared equity. The measures taken in the Netherlands are less comprehensive than those in the UK but comparable in terms of substance. As in the UK, they aim to support households facing payment problems, ensure the continuation of new construction projects jeopardised by the crisis and enable housing associations to buy up new dwellings that remain unsold.

\section{Explanations for variations in impacts (a) the economics of housing market volatility}

We have shown that the crisis had varying impacts on house prices and sales. One explanation may be found in the proposition that these short-term differences were linked to underlying variations in the long-term volatility of housing markets. The key question then becomes: Why does house price and supply volatility vary markedly from one country to another? Basic economics suggests that fluctuations in owner-occupier house prices and supply are essentially determined by housing demand and supply. Housing demand has been shown in many empirically verified models to be a function mainly of disposable household income, the cost and availability of mortgage finance, expectations about future price rises and levels of employment and consumer confidence. Some studies also point explicitly to the relative costs of owning and renting (Hilbers et al. 2008). All of these items are linked to a greater or lesser extent to changes in the macro economy and the policies that governments use to influence inflation, growth and employment. These macroeconomic factors combine with demographic factors to determine the number of households seeking housing and their financial ability to purchase it. International variations in macroeconomic and demographic factors thus offer one set of potential explanations for differences in the stability of housing markets (Tsatsaronis and Zhu 2004; Hilbers et al. 2008; André 2010).

Alongside the macroeconomic factors one could identify the importance of mortgage markets and seek explanations that depend mainly on the structure and operation of these markets. Institutional arrangements that influence the supply of mortgage credit and the terms on which this is available to households vary considerably from country to country (Renaud and Kim 2007). Thus the size of deposits and interest rates, and the variability in each of these, offer another set of potential explanations within the broader context of the institutional arrangements relating to mortgage markets. There may also be important links between inflation, mortgage markets and real house prices (Tsatsaronis and Zhu 2004).

Supply-side explanations for price fluctuations typically concentrate on factors that may contribute to inelasticity. In that vein, demand increases will arguably result in steeper price rises in countries where there are the most severe constraints on increases in supply, while differences in the responsiveness of housing supply to changes in demand are arguably a principal course of variations in house price fluctuations (White and Allmendinger 2003; Meen 2008; Hilbers et al. 2008). These constraints can be apparent in land, labour and capital markets or more generally take the form of production capacity 
limitations. Many studies emphasise land supply constraints resulting from restrictive planning systems that constrain the ability of residential developers to expand output when housing demand rises (Barker 2004).

Despite the supply-side studies that emphasise inelasticity, much of the theorising about housing market stability concentrates on external influences on housing demand. These influences, which may have their origins in macroeconomics and demographics, are not the central concern of this contribution. Instead we seek to put the structure of housing systems at the centre of the discussion. So, given world-wide changes in housing demand fuelled by an international crisis, we probe the varying responses within housing markets and the varying policy responses by governments that are tied to differences in the structures of housing systems. These differences in structures are linked to differences in mortgage markets, planning and development systems and the different ways in which house building industries operate. They are also linked to differences in turnover in the existing stock and the structure of total supply which is a function of sales from the existing stock and new production.

\section{Explanations for variations in impacts (b) housing system approaches}

In order to probe the differences in institutional arrangements that are associated with variations in housing market structures it is useful to take an approach that looks at differences in housing systems. Following Bekebrede and Mayer (2006) we define a (housing) system as being composed of organised parts that interact in space and time. Important parts within a housing system are demand, supply and institutions. On the demand side, households with their housing preferences are the key players. On the supply side, agents producing dwellings and housing services, such as building companies, developers, commercial and social landlords, are the key agents. Institutions are the rules, norms and regulations by which a system functions (Keogh and D'Arcy 1999 in Oxley 2004). Demand, supply and institutions meet on the housing market, where the outcomes of the system are the consequence. Since the housing system is part of a broader societal system the different parts of the housing system are influenced by broader 'external' factors like economic, socio-cultural and demographic developments. And of course housing outcomes have an impact on these broader outcomes. Especially the formal and informal institutional arrangements which have developed over time play an important role in the structure of housing systems and thus in the way 'external' developments influence housing outcomes (Kemeny 1995). In a comparative perspective this means that because the housing system in different countries is structured in a different way, comparable 'external' developments like an economic crisis may lead to different housing outcomes. These differences in housing outcomes between countries in relation to differences in the structure of housing systems form the point of departure in this contribution.

\section{Dynamic versus static housing systems: the theory}

In our analysis of the relation between housing outcomes and the structure of housing systems we make a distinction between dynamic and static housing systems. This distinction is based on work by Ball et al. (1988) and Martens (1990). In their work they distinguish between unified and fragmented or segmented markets. In unified markets both new and existing dwellings compete for would-be purchasers, and the transactions of the 
large number of existing dwellings and households influence new housing construction. All parts of the national owner-occupied housing market are linked by common market forces. Fragmented owner-occupied markets are dominated by first-time buyers and consist of a variety of sub-markets, differentiated by region or housing sector. Fragmentation is encouraged by the low rate of mobility of existing homeowners. New housing meets localised demand (Ball et al. 1988: 113-114). Besides this, Ball et al. (1988) and Martens (1990) distinguish between different 'forms of owner-occupied housing provision'. Forms of housing provision are defined by the relations between those who initiate and control house building and the other institutions and agencies that are part of the development process (Martens 1990: 50). Forms of owner-occupied housing provision include speculative promotion, speculative house building and self-building or self-commissioned house building where individuals build for their own use. Thus the development process is initiated and controlled by future owner-occupiers, using land which they acquire themselves (Ball et al. 1988). Although Martens (1990) and Ball et al. (1988) do not point to a direct relation between different markets and different forms of housing provision, selfbuilding or self-commissioned house building is more likely in fragmented markets with low household mobility and speculative promotion or speculative building in unified markets with high household mobility. So in our distinction between dynamic and static housing systems we combine 'housing market structures' with 'forms of housing provision' and focus on the role of household mobility. We could alternatively speak of low turnover versus high turnover systems when we refer to static and dynamic housing systems. In the following subsections we elaborate more on our views of dynamic and static housing systems and we state our expectations with regard to the crisis-sensitivity of these systems.

\subsection{Dynamic housing systems}

Dynamic housing systems are based on a process of gradually moving up and down the property chain and consist of a market for new construction in which owner-occupied housing is primarily built by commercial market players who develop properties at their own risk. They offer newly built dwellings on the free market via estate agents or their own sales channels. In economic booms, the construction of new dwellings is often targeted at the upper end of the market (Ball et al. 1988). Via relatively long housing chains, the construction of a new dwelling at the upper end of the owner-occupied housing market ultimately results in a property becoming available for a first-time buyer at the lower end of the market. As their housing preferences change, many homeowners opt to move house rather than extend or renovate their existing property. These changing preferences may be the result of changes in the composition of the household or in income. As a consequence, these types of markets tend to have high levels of mobility and a large number of transactions of existing owner-occupied dwellings.

New residential development and construction by market parties in dynamic housing systems may involve varying degrees of speculation or risk. One way of reducing risk is to sell newly built dwellings at the initial planning stage; the start of construction is delayed until a specific percentage of dwellings have been sold. Speculative building involves a much greater level of risk as owner-occupied dwellings are sold either during or after construction (Golland and Blake 2004). If the demand for owner-occupied dwellings drops, developers can be left with unsold properties on their hands.

It is likely that a dynamic system, based on a high level of mobility, will be highly vulnerable to economic trends because it relies on households who already own a good 
dwelling trading up to a larger, more expensive property. In times of economic prosperity, the demand for dwellings increases and prices rise. In this situation, homeowners will be more likely to move up the housing ladder and purchase a more expensive dwelling. In this process, an increase in the price of owner-occupied dwellings further stimulates the demand for such properties (Stein 1995). This is because investing in a dwelling in a rising market not only offers the benefits of the dwelling itself, but it also offers the prospect of a high return on the investment. In general, in dynamic housing systems dwellings are an asset or investment. As a result, rising house prices may also attract investment in private rented housing (buy-to-let).

When house prices rise, existing homeowners find it relatively easy to climb the housing ladder into a better property, because they can take along the increased equity from their existing dwelling (Stein 1995). However, it becomes increasingly difficult for first-time buyers to enter the owner-occupied market and this process of trading up can ultimately stagnate because of falling demand at the lower end of the market. This can lead to a temporary reduction in the number of transactions in the market for existing owneroccupied properties, a decrease in housing production and a downward price correction.

In a period of economic recession, there is diminished confidence that incomes and house prices will rise. For this reason, many homeowners delay moving house, deterred by the prospect of investing in a more expensive dwelling that may fall in value. As a result, fewer dwellings are sold and mobility decreases. This can lead to a downward price correction, although many sellers are willing to accept longer selling times instead of lowering the list price (Engelhardt 2003). When the confidence of consumers in the housing market is low and more households face problems in meeting payments, eventually house prices will fall. If this situation is combined with few spatial planning restrictions on residential construction and with speculative building, a fall in demand can trigger a stronger price response. This is because many project developers have started building houses in the previous prosperous era and now, as demand suddenly falls, are left with large numbers of unsold dwellings, which creates an excess of supply and subsequently puts an additional downward pressure on house prices.

\subsection{Static housing systems}

In static housing systems, private individuals who commission the construction of new residential properties play a major role. These are often detached properties built on a plot owned or acquired by the individual. This individual buys a plot and, usually in consultation with an architect, arranges the required planning permission and coordinates the design, the issuing of tenders to contractors and, ultimately, the construction (see for example Ball et al. 1988; Dol et al. 2010b). In this kind of housing market, changing housing preferences are less likely to result in people moving house but rather in modifying their existing home. Consumers in static housing systems generally buy only one or at most two dwellings in their entire housing career. As a consequence, the system is typified by low levels of mobility and short housing chains. This therefore means that the number of transactions in the market for existing owner-occupied dwellings is relatively limited. In markets where self-provided housing plays an important role, the influence of economic trends on the housing market is likely to be less significant (Barlow and Duncan 1994: 148). The construction of new properties focuses less on the upper end of the market and is more driven by actual housing needs.

In view of this limited mobility, changes in the prices of existing owner-occupied dwellings play a less significant role in a static system. In this kind of market, dwellings are 
not regarded so much as an investment whose value will hopefully increase, but rather as consumer goods (see also Duncan and Rowe 1993). Of course, in a static system, an economic recession will also lead to a reduction in the number of transactions in the existing stock and a decrease in the production of new dwellings, but its effects are relatively limited. Indeed, for households with secure employment, an economic recession can even prove attractive because it generally provokes a drop in the prices of building materials, making the cost of construction relatively low (see Duncan and Rowe 1993). In general terms, trends in the costs of construction and land have a greater relation with house prices in a static system than they do in a dynamic system. This is because the process of trading up in a dynamic system means that the number of transactions involving existing dwellings is many times greater than the number of new dwellings, and the price of existing owner-occupied dwellings therefore determines the price of new properties (Boelhouwer et al. 2006).

\section{Dynamic versus static housing systems: the application to several countries}

\subsection{The countries classified by type of housing system}

As we argued, the number of transactions on the market for existing owner-occupied dwellings is an important feature distinguishing between dynamic and static housing systems. For this reason, Table 4 shows the number of transactions involving existing (owner-occupied) dwellings per 1,000 owner-occupiers in the selected countries. The table shows a clear distinction, at least until 2007, between the number of transactions per 1,000 owner-occupiers in the United Kingdom, Ireland and the Netherlands on the one hand and Germany and Belgium on the other. The effect of the economic crisis in 2008 on the number of transactions is also much more evident in these first three countries than it is in Belgium and Germany.

A second feature distinguishing between static and dynamic housing systems is the level of self-provided housing. Table 5 shows that self-provision plays an important role in Germany and Belgium and that only in Germany has the level of self-provided housing increased since 1990. This high level of self-provision in Germany is partly a consequence of the fact that dwellings are commissioned by private individuals for renting out. A comparison between Tables 3 and 4 shows that with regard to the 'ranking' of countries the number of transactions mirrors the percentage of self-provided housing. Countries like

Table 4 Transactions per 1,000 owner-occupiers in five West European countries, 2000-2008

\begin{tabular}{lcccccccccc}
\hline $\begin{array}{l}\text { Transactions/1,000 } \\
\text { owner-occupiers }\end{array}$ & 2000 & 2001 & 2002 & 2003 & 2004 & 2005 & 2006 & 2007 & 2008 & $\begin{array}{l}\text { Average } \\
2000-2008\end{array}$ \\
\hline UK & & 85.1 & 91.9 & 83.7 & 83.0 & 71.1 & 88.0 & 83.8 & 43.1 & 70.0 \\
The Netherlands & 51.8 & 53.1 & 53.5 & 49.1 & 48.5 & 52.0 & 52.7 & 50.8 & 45.7 & 50.8 \\
Ireland & 47.8 & 39.4 & 50.6 & 55.3 & 50.8 & 56.8 & 54.3 & 42.1 & 25.3 & 46.9 \\
Belgium & 36.9 & 37.8 & 39.6 & 40.5 & 40.4 & 40.0 & 40.6 & 41.7 & 39.9 & 39.7 \\
Germany & 30.8 & 31.7 & 30.3 & 29.8 & 26.7 & 30.5 & 26.8 & 27.6 & 27.1 & 29.0 \\
\hline
\end{tabular}

Source: All statistics in this table are OTB Research Institute calculations. Number of owner-occupiers is calculated on the basis of data from Housing Statistics in the EU (Federcasa 2006). Transactions in Germany from Hypostat 2008. All other data used for the calculations are from national statistical bureaus 
Table 5 Self-provided housing as a percentage of total housing production in five West European countries, 1990-2004/2005

\begin{tabular}{llc}
\hline & 1990 & $2004 / 2005$ \\
\hline UK & 10 & n.a. \\
The Netherlands & 17 & 11 \\
Ireland $^{\mathrm{a}}$ & 40 & 26 \\
Belgium $_{\text {Germany }}^{\mathrm{b}}$ & 71 & 52 \\
\hline
\end{tabular}

Source: National Statistics Institutes (Belgium, Germany and the Netherlands), Barlow et al. (2001) (UK), Ministry of Environment, Heritage and Local Government (Ireland)

${ }^{a}$ New individual houses

b Part of these dwellings are commissioned by private individuals for renting out

Belgium and Germany with a static housing system have the least transactions per 1,000 owner-occupiers and at the same time the highest level of self-provided housing. In the UK, the Netherlands and Ireland we see a high level of transactions and a lower degree of self-provision.

The two countries with a static housing system differ from each other in so far as Belgian households tend to invest in their own home at an earlier age. Indeed, De Decker (2008) highlights a long-standing practice involving the private commissioning of construction whereby families often own plots of land which are passed on to children when they reach adulthood and much of the construction is done independently. This practice has been partly facilitated by the traditional laissez-faire attitude adopted by Belgian spatial planning policy. However, since the start of this millennium, there has been some tightening in Belgian spatial planning policy. Practice in Germany differs from that in Belgium because people tend to enter the owner-occupied housing market at a later age. The fact that households in Germany delay the move to their own home until a later age is partly a consequence of the way in which ownership is financed. This also encourages the construction of relatively large and high-quality dwellings. Up to the age of 35, people tend to make use of the extensive and affordable rental housing market (Tegeder and Helbrecht 2007). Most German households do not buy a dwelling more than twice in a lifetime.

The Dutch, British and Irish housing systems are dynamic in character. In Ireland, the development of a high turnover market based on a process of trading up is a recent trend triggered in part by the strong economic growth experienced in this country in recent decades. This strong economic growth led to a very high level of housing production which facilitated movements to newly built dwellings and within the housing stock. Due to rapid house price increases (new) dwellings became popular as an investment. So from the mid1990s the buy-to-let sector grew fast in Ireland, as was the case in England (Dol et al. 2010a). ${ }^{3}$ Important differences between the Netherlands, Britain and Ireland are related to the extent to which there is speculative construction and the spatial planning possibilities for realising residential properties. In the Netherlands, risks are limited by selling new dwellings at the initial planning stage. In such cases, the start of construction is delayed until a specific percentage of dwellings have been sold (usually around 70\%). This percentage of pre-sales is an integral part of the construction process required by funding

\footnotetext{
3 In the Netherlands buy-to-let is less popular because house prices are 'based' on the existence of full mortgage interest tax relief (see Sect. 9), which is restricted to one dwelling.
} 
bodies and for construction guarantees. ${ }^{4}$ In the UK and Ireland, there is more speculative construction and new owner-occupied homes are generally sold during or after construction (see Barker 2004; Murphy 1995). This entails a much greater level of risk for market players. If the demand for owner-occupied dwellings drops, developers can be left with unsold properties on their hands. Where speculative building is combined with a generous spatial planning policy, like in Ireland, the risk of unsold newly built dwellings will be even bigger. A restrictive planning policy, like in the Netherlands and England, diminishes this risk. On the other hand a restrictive planning policy inhibits supply when demand is high, resulting in strong price increases (Barker 2008; Ball 2004; Vermeulen and Rouwendaal 2007).

The difference between dynamic and static systems outlined above is of course based on generalisations and does not apply in every case. Private individuals also commission the construction of their own homes in the Netherlands, the UK and Ireland. Equally, there are also developers in Belgium and Germany who market new-build properties at their own risk. For example, in urban areas in Belgium project developers have increasingly been building owner-occupied apartment complexes. There is also of course a market for existing homes in Germany and in Belgium, since not everyone builds or commissions their own home. In addition, housing markets also undergo development. For example, the process of trading-up rapidly increased during the 1970s and 1980s in the Netherlands' housing market. This trend started only recently in Ireland and, as indicated above, the role of project developers is also starting to make its mark in Belgium, primarily in the construction of apartments.

\section{Dynamic versus static housing systems: stabilising factors}

\subsection{Owner-occupied housing sector}

The operation of mortgage finance systems and the nature of government influence on these systems provides varying degrees of built-in automatic stabilisation. Table 6 includes an overview of types of financing for home ownership and government policies applied in the five countries studied.

In the UK and Ireland, two of the countries with dynamic systems, there are hardly any stabilising factors in the housing market. If available at all, mortgage interest tax relief is only limited and variable interest rates are often applied, which means that changes in interest rates have a direct impact on households' housing expenditure. In addition, there are relatively high LTVs (80-100\%) and LTIs, which means that households who have recently purchased a home in particular can face immediate affordability problems through an increase of interest rates. During an economic recession, when households face a drop in income or have low expectations with regard to potential improvements in income, the process of trading up tends to stagnate. Moreover, the price of owner-occupied housing is increasingly determined by relatively low proceedings from repossessions of home owners who are no longer able to meet their mortgage payment commitments as a result of an interest rate increase or a drop in income. In Ireland, this impact might be felt more intensely than in the UK as there is no additional crisis measure that covers high housing

\footnotetext{
4 This guarantee, initiated by the Dutch building industry after a crisis in the housing market in the early 1980s, guarantees the buyer that the dwelling will be finished in case of bankruptcy of the developer during the building process.
} 


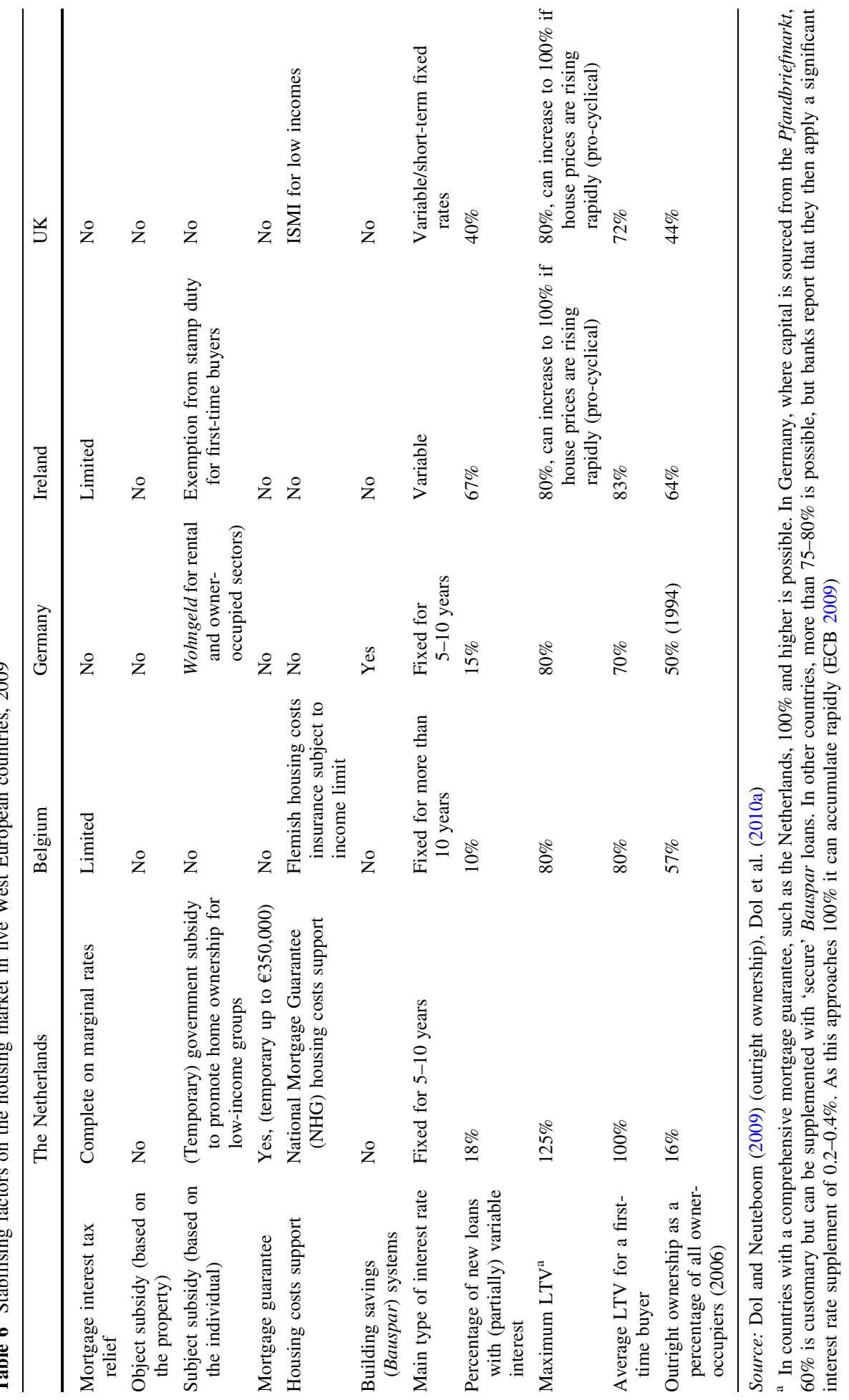


costs. In addition, because much of the residential construction both in the UK and Ireland is speculative in nature, an economic downturn can lead to new residential properties becoming unsaleable and remaining vacant. In Ireland, where there are relatively loose spatial planning restrictions on the construction of new residential properties, this impact could be felt more keenly than in the UK where spatial planning policy is more restrictive.

In the Netherlands, the third country with a dynamic system, there are more stabilising factors to support the owner-occupied housing market. Mortgage interest tax relief and the often extended periods of fixed interest rates create a buffer that protects against fluctuations in interest rates or in owner-occupiers' ability to keep up payments. On the other hand, the LTVs for first-time buyers on the housing market are very high and the level of outright ownership is low. Despite the existence of both the national mortgage guarantee, which covers the risks of funding bodies, and (limited) housing costs insurance, the high LTVs and LTIs still present a risk, primarily for recent buyers who face a drop in income. This is especially the case if this coincides with a drop in house price. The risk of unsaleable, vacant new residential properties is limited in the Netherlands because of the process of pre-selling generally applied. Construction of new residential properties is delayed until around $70 \%$ of dwellings have been sold.

In Belgium and Germany, which have a static housing system, the way in which home ownership is financed represents a significant stabilising factor in the owner-occupied housing market. In these cases, the maximum LTVs are lower than in the other three countries and long periods at fixed interest rates are more common. Facilities are also available for households unable to meet their housing expenditure as a result of a drop in income, either in the form of an individual subsidy (Wohngeld in Germany) or as housing cost insurance funded by local government (Flanders).

\subsection{Rental sector}

The rental sector can also affect the stability of the housing market. Trends in the market value of residential properties and changes in the ability of households to make payments have an indirect effect on large parts of the rental property market in most countries. ${ }^{5}$ There is however, no direct relationship between the house prices and rents. The ability to meet payment commitments depends on the relationship between the rent and income. Because rents (for existing contracts) are regulated in many countries (at least in the social rental sector) and/or there are subject subsidies or income-related rents available, the influence of the economy on tenants' ability to meet their payment commitments is relatively limited (see Table 7).

Because the rental sector is less vulnerable to economic trends than the owner-occupied sector, the stability of the total housing market depends on the size of the rental sector. If it is large, this means that any economic effects on the owner-occupied housing market affect only a limited number of households. In this respect, the rental sector in Germany and the Netherlands is a much more significant stabilising factor on the housing market than it is in Ireland, Belgium and the UK. A comparative OECD study (André 2010: 33) suggests that the existence of well-functioning rental markets can help to reduce the volatility of house prices: "When house prices rise relative to rents, an increasing share of households should opt for renting, thereby reducing pressures on prices".

\footnotetext{
${ }^{5}$ For landlords, the effect of developments in the market value of dwellings may be reasonably compared with that for owner-occupiers: changes in value primarily play a role in sales and the decision on whether or not to sell.
} 
Table 7 Stabilising/destabilising factors in the rented sector in five West European countries, 2009

\begin{tabular}{|c|c|c|c|c|c|}
\hline & $\begin{array}{l}\text { The } \\
\text { Netherlands }\end{array}$ & Belgium & Germany & Ireland & UK \\
\hline $\begin{array}{l}\text { Rent adjustments for } \\
\text { social renting }\end{array}$ & Regulated & Regulated & Regulated & Regulated & Regulated \\
\hline $\begin{array}{l}\text { Subject subsidies for } \\
\text { social renting }\end{array}$ & Yes & $\begin{array}{l}\text { Income- } \\
\text { related } \\
\text { rents }\end{array}$ & $\begin{array}{l}\text { Yes (via Wohngeld or } \\
\text { social insurance) }\end{array}$ & Yes & Yes \\
\hline $\begin{array}{l}\text { Rent adjustments for } \\
\text { private renting }\end{array}$ & $\begin{array}{l}\text { Regulated (up } \\
\text { to a limit) }\end{array}$ & Regulated & $\begin{array}{r}\text { Market-related } \\
\text { (Mietspiegel) }\end{array}$ & $\begin{array}{l}\text { Not } \\
\quad \text { regulated }\end{array}$ & $\begin{array}{l}\text { Not } \\
\text { regulated }\end{array}$ \\
\hline $\begin{array}{l}\text { Subject subsidy for } \\
\text { private renting }\end{array}$ & Yes & No & Yes & Yes & Yes \\
\hline $\begin{array}{l}\text { Size of the rented } \\
\text { sector }\end{array}$ & $49 \%$ & $25 \%$ & $57 \%$ & $18 \%$ & $30 \%$ \\
\hline
\end{tabular}

Source: Haffner et al. (2009)

Finally, as a result of anti-cyclical housing production, the rental sector can play a more direct role in mitigating the effects of a recession. This may involve the construction of rental properties or the buying up of unsaleable new-build homes. In four of the five countries studied the social rental sector can only play this role when supported by government subsidies. It is only in the Netherlands that the social rental sector can fulfil such a role without additional government support.

So in two of the three countries with a dynamic housing system, England and Ireland, there are few stabilising factors through government policy or via the financing industry. Moreover, new dwellings are built speculatively and in Ireland this is combined with relatively light planning restrictions. In the Dutch housing market there are more stabilising factors, among which is a large and financially independent social rented sector. Some of these factors (mortgage guarantee and housing costs support) may be seen as a compensation for full mortgage interest tax relief, which results in high LTVs and a low percentage of outright ownership. In Germany and Belgium, countries with a static housing system, the main stabilising factor in the housing market is the way in which home ownership is financed. In Germany the large rental sector is an additional stabilising factor in the housing system.

\section{Conclusions}

We have examined the housing market impacts and the housing policy impacts of the international financial crisis in several European countries. We have argued that both sets of impacts have differed markedly between countries. The differences between countries can, it has been shown, be explained in terms of differences in housing systems. We have distinguished between dynamic and static systems.

In a dynamic system additions to the stock come mainly from speculative house building and there is a high rate of turnover in the existing stock. This results in a large volume of transactions in the owner-occupied stock relative to the number of homeowners. The high level of household mobility that characterises this system is essential to the functioning of the market and the demand for new dwellings. With rising demand and rising prices home ownership has a high level of attraction as an asset and trading-up is 
common. The system depends strongly on fresh waves of first-time buyers entering the market. When these first-time buyers find purchasing more difficult, downward trends in prices and transactions follow speedily.

In static systems there is more self-build and less speculative development and lower levels of household mobility. Changes in demand are more reflected in adaptations to existing dwellings and less in moves to new dwellings. House prices are more linked to supply-side factors such as building and land costs than in the dynamic model. Transitions are lower and house price inflation is less driven by rising demand and speculative purchases.

In our comparison, the Netherlands, Ireland and the UK can be typified as having dynamic systems and Belgium and Germany as more static systems. However, rather than a crude division of the countries according to two categories it is better to see the first three countries at one end of a dynamic/static spectrum and the remaining two at the other end. In the more dynamic countries the impact of the crisis on house prices, production and transactions was more marked than in the countries with more static systems. The policy responses by governments accordingly differed between the countries. We have made a distinction between policy responses that have focused on financial institutions and those that have focused on housing demand and output. Our main concern has been to emphasise the variations in the housing-specific responses. Whilst there were few housing (as opposed to financial market) measures in Belgium and Germany there were significant sets of housing policy responses in the other three countries. These measures were aimed at reducing the risk of mortgage default, boosting the demand for housing and assisting the construction industry. We have further shown that the differences between the countries are linked to the (built-in) stabilising factors in each country. These stabilisers relate to the operation of mortgage markets, government support for mortgage markets, the size of the home ownership sector relative to the rented sector and the support provided for tenants.

The extent to which the housing market has been affected by the crisis appears to be in line with our assumptions about the sensitivity of the different housing systems: dynamic markets are more sensitive than static markets. The effects of the crisis on the owneroccupied market are strongest in Ireland, followed by England. In these countries the fall in house prices and transactions of existing and new dwellings was largest. These countries have limited stabilising factors through government policy or via the financing industry. Moreover, new dwellings are built speculatively and in Ireland this is combined with relatively light planning restrictions. With regard to the other three countries it seems that the Dutch market for new dwellings has been hardest hit, while in Germany the prices of existing dwellings show a relatively strong decline. This house price decline in Germany is partly a result of the housing surpluses that existed before the crisis in many parts of the country. The fact that the Dutch housing market has been less hit than the English and Irish may be attributed to the many stabilising factors in the Dutch housing market. The Belgian (Flanders) housing market, a clear example of a static owner-occupied market, seems to experience the least trouble from the economic crisis.

However, the extent to which the general economies of the five nations have been affected by the crisis seems to follow the same pattern. Countries that have been severely affected are also confronted with the largest problems on the housing market. It is not always possible to establish to what extent developments on the housing market are influenced by structures of the housing system and the stabilising factors. The question remains whether the large problems on the Irish and English housing markets are a result of the structure of the housing system or whether these are a result of the stronger impact of the economic crisis in general. Possibly there is a relation between the general economic 
structure and the housing market structure which would result in a process where a nation that is highly sensitive to the general economic climate also has a housing system structure that is sensitive to the economic climate.

Making a distinction between static and dynamic housing systems provides a new and fruitful way to classify housing systems and explain why the international financial crisis had different impacts in different countries. This perspective is most usefully viewed as complementary, rather than as an alternative, to the sets of explanations that arise from economic theories that seek to understand differences in housing market volatility as a consequence of varying determinants and varying levels of housing demand and supplyside inelasticity.

Acknowledgments The authors would like to thank three anonymous referees for helpful comments and suggestions.

Open Access This article is distributed under the terms of the Creative Commons Attribution Noncommercial License which permits any noncommercial use, distribution, and reproduction in any medium, provided the original author(s) and source are credited.

\section{References}

André, C. (2010). A bird's eye view of OECD housing markets. OECD Economics Department working papers, number 746. Paris: OECD Publishing.

Ball, M. (2004). RICS European housing review 2003. London: RICS.

Ball, M., Harloe, M., \& Martens, M. (1988). Housing and social change in Europe and the USA. London and New York: Routledge.

Bank of England. (2010). Table LPQB46A, Quarterly changes of total sterling housing equity withdrawal. Bank of England website, database accessed 25 October 2010.

Barker, K. (2004). Delivering stability: Securing our future housing needs. London: HM Treasury.

Barker, K. (2008). Planning policy, planning practice and housing supply. Oxford Review of Economic Policy, 24(1), 34-49.

Barlow, J., \& Duncan, S. (1994). Success and failure in housing provision, european systems compared. Oxford, New York and Tokyo: Pergamon and Elsevier Science Ltd.

Barlow, J., Meikle, J. L., \& Jackson, R. (2001). Homes to DIY for: The UK's self-build housing market in the twenty-first century. York: Joseph Rowntree Foundation.

Bekebrede, G., \& Mayer, I. (2006). Build your seaport in a game and learn about complex systems. Journal of Design Research, 5(2), 273-298.

Boelhouwer, P. J., Boumeester, H. J. F. M., \& Van der Heijden, H. M. H. (2006). Stagnation in Dutch housing production and suggestions for a way forward. Journal of Housing and the Built Environment, 21(3), 299-314.

Brunnermeier, M. (2009). Deciphering the liquidity and credit crunch 2007-2008. Journal of Economic perspectives, 23(1), 77-100. Winter.

CML, Council of Mortgage Lenders. (2008). Tighter lending criteria and falling house prices discourage first-time buyers. Press release of 9 September.

De Decker, P. (2008). Facets of housing and housing policies in Belgium. Journal of Housing and the Built Environment, 23, 155-171.

Dol, K., \& Neuteboom, P. (2009). Macro change and micro behaviour: The effects of aging on tenure choice, and households' strategies towards the use of housing wealth. Delft: OTB Research Institute for Urban, Housing and Mobility Studies.

Dol, K., Lennartz, C., \& Van der Heijden, H. (2010a). Particulier opdrachtgeverschap in België en Duitsland: de cases Vlaanderen en Nordrhein-Westfalen. (Self Provided Housing in Belgium and Germany: The cases of Flanders and North-Rhine Westphalia). Delft: Delft University of Technology, OTB Research Institute for Urban, Housing and Mobility Studies.

Dol, K., Van der Heijden, H., \& Oxley, M. (2010b). Economische crisis, woningmarkt en beleidsinterventies: een internationale inventarisatie (Economic crisis, housing market and policy measures; an international comparison). Delft: Delft University of Technology, OTB Research Institute for Urban, Housing and Mobility Studies. 
Duncan, S., \& Rowe, A. (1993). Self-provided housing: The first world's hidden housing arm. Urban Studies, 30(8), 1331-1354.

ECB, European Central Bank (2009). Housing finance in the Euro area. Occasional paper series, no 101/March. Frankfurt am Main: European Central Bank.

Engelhardt, G. V. (2003). Nominal loss aversion, housing equity constraints and household mobility: Evidence from the United States. Journal of Urban Economics, 53, 171-195.

Federal Reserve. (2008). The April 2008 senior loan officer opinion survey on bank lending practices. Board of Governors of the Federal Reserve System, May 5.

Federcasa. (2006). Housing statistics in the European union 2005/2006. Rome: Ministry of Infrastructure of the Italian Republic.

Freddie Mac. (2010). Cash out refinance report 2010 Q2. Office of the Chief Economist. Freddie Mac website, database accessed 25 October.

Golland, A., \& Blake, R. (Eds.). (2004). Housing development, theory, process and practice. London and New York: Routledge.

Haffner, M., Hoekstra, J., Oxley, M., \& Van der Heijden, H. (2009). Bridging the gap between social and market rented housing in six European countries? Housing and urban policy studies 33. Amsterdam: IOS Press.

Hartmann, P. (2009). The financial crisis and policy responses. ECB, DG Research.

Hilbers, P., Hoffmaister, A.W., Banerji, A., \& Shi, H. (2008). House price developments in Europe: A comparison, IMF working paper.

Kemeny, J. (1995). From public housing to social renting: Rental policy strategies in comparative perspective. London: Routledge.

Keogh, G., \& D’Arcy, E. (1999). Property market efficiency: An Institutional economic approach. Urban Studies, 36(13), 2401-2414.

Martens, M. (1990). Ways of owning, a study of homeownership in Europe and the USA (Thesis). Department of Sociology, University of Essex, Essex.

Meen, G. (2008). The new propositions in UK housing macroeconomics; An overview of the first years of the century. Urban Studies, 45(13), 2759-2781.

Mortgage Bankers Association. (2007). Delinquencies and foreclosures increase in latest MBA National delinquency survey. Press release of 3/13/2007.

Murphy, L. (1995). Mortgage finance and housing provision in ireland, 1970-90. Urban Studies, 32(1), $135-154$.

Oxley, M. (2004). Economics, planning and housing. Basingstoke: Palgrave Macmillan.

Renaud, B., \& Kim, K.-H. (2007). The global housing price boom and its aftermath. Housing Finance International, 22(2), 3-15.

Stein, J. (1995). Prices and trading volume in the housing market. A model with downpayment constraints. Quarterly Journal of Economics, 110, 379-406.

Tegeder, G., \& Helbrecht, I. (2007). Germany. Home ownership, a Janus-faced advantage in time of welfare restructuring. In M. Elsinga, P. de Decker, J. Toussaint, \& N. Teller (Eds.), Beyond asset and insecurity: On (in)security of home ownership in Europe. Amsterdam: IOS Press.

Tsatsaronis, K., \& Zhu, H. (2004). What drives housing market dynamics; cross-country evidence. BIS Quarterly Review, March, 65-78.

Vermeulen, W., \& Rouwendaal, J. (2007). Housing supply in the Netherlands, CPB discussion paper. The Hague: CPB.

White, M., \& Allmendinger, P. (2003). Land-use planning and the housing market: A comparative review of the UK and the USA. Urban Studies, 40(5-6), 953-972. 